\title{
PERBEDAAN LUARAN PASIEN STROKE ISKEMIK AKUT DENGAN LEUKOSIT NORMAL DAN LEUKOSITOSIS
}

\author{
DIFFERENCE IN OUTCOME OF ACUTE ISCHEMIC STROKE PATIENT \\ WITH NORMAL LEUKOCYTE AND LEUKOCYTOSIS
}

Clarissa Tertia, * Belinda Orline Olivia Singgih, * I Ketut Sumada, * Ni Ketut Candra Wiratmi, *

I Putu Eka Widyadharma**

\begin{abstract}
Introduction: Inflammation is an independent risk factor for ischemic stroke, which needs to be inhibited to reduce worsening occlusion of arteries due to atherosclerotic plaques. Increased leukocyte count is considered an acute damage marker of brain tissue that experiences ischemia and is used to determine the severity and prognosis of acute ischemic stroke.
\end{abstract}

Aims: To analyse association between the number of leukocytes in acute onset ischemic stroke patients during admission and discharge.

Methods: A prospective analytical observational study with a cohort design on acute ischemic stroke patients in Wangaya Regional Hospital, Denpasar-Bali between January and September 2018. Clinical manifestations were assessed using National Institutes of Health Stroke Scale (NIHSS). Data was collected through medical records and analysed using Chi-square test and Mann-Whitney.

Results: Seventy-six subjects devided into 2 groups; normal leucocytes and leucocytosis group, 38 patients respectively. The normal leucocytes group was dominated with male subject (78.9\%) and mean leucocytes count was $7,612 / \mathrm{mm}^{3}$. While leucocytosis group was dominated with female subjects (63.2\%) and mean leucocytes count was 12,294/ $\mathrm{mm}^{3}$. Mean NIHSS at admission in normal leucocytes group and leucocytosis group was 5 (moderate) and 8 (moderate) respectively. Mean NIHSS at discharge in normal leucocytes group and leucocytosis group was 3 (low) and 11 (moderate) respectively.

Discussion: Patients with acute onset ischemic stroke with normal leukocyte count during admission, tend to have better clinical outcome two times fold compared to the patients with leucocytosis.

Keywords: Leukocytes, leucocytosis, acute ischemic stroke, NIHSS

\section{ABSTRAK}

Pendahuluan: Inflamasi merupakan faktor risiko independen terjadinya stroke iskemik, yang perlu dihambat untuk mengurangi perburukan oklusi pada pembuluh darah akibat plak aterosklerotik. Peningkatan kadar leukosit dianggap menunjukkan kerusakan akut jaringan otak yang mengalami iskemia dan digunakan untuk mengetahui tingkat keparahan dan prognosis stroke iskemik akut.

Tujuan Mengetahui hubungan antara kadar leukosit terhadap manifestasi klinis pasien stroke iskemik onset akut pada saat masuk dan keluar perawatan.

Metode: Penelitian observasional analitik prospektif dengan rancangan kohort terhadap pasien stroke iskemik onset akut yang dirawat di RSUD Wangaya, Denpasar, pada bulan Januari hingga September 2018. Manifestasi klinis subjek dinilai berdasarkan derajat beratnya stroke menggunakan National Institutes of Health Stroke Scale (NIHSS). Data dikumpulkan melalui rekam medis dan di analisis dengan uji Chi-square dan Mann-Whitney.

Hasil: Didapatkan 76 subjek yang dibagi menjadi 2 kelompok, yaitu masing-masing 38 subjek pada kelompok dengan leukosit normal dan kelompok dengan leukositosis. Kelompok subjek leukosit normal, didominasi oleh subjek lakilaki $(78,9 \%)$ dan rerata kadar leukosit $7.612 / \mathrm{mm}^{3}$, sedangkan pada kelompok leukositosis mayoritas perempuan (63,2\%) dan rerata kadar leukosit $12.294 / \mathrm{mm}^{3}$. Rerata skor NIHSS saat masuk pada kelompok leukosit normal adalah 5 (moderat) dan pada kelompok dengan leukositosis adalah 8 (moderat). Adapun rerata skor NIHSS pada kelompok leukosit normal saat pasien keluar adalah 3 (ringan) dan 11 (moderat) pada kelompok leukositosis.

Diskusi: Subjek stroke iskemik akut dengan kadar leukosit awal yang normal cenderung memiliki perbaikan manifestasi klinis pada saat keluar RS dua kali lebih baik daripada subjek dengan leukositosis.

Kata kunci: Leukosit, leukositosis, stroke iskemik akut, skor NIHSS

*Departemen Neurologi RSUD Wangaya, Bali, Indonesia; **Departemen Neurologi FK Universitas Udayana/RSUP Sanglah, Bali, Indonesia. Korespondensi: clarissa_tertia@yahoo.com. 


\section{PENDAHULUAN}

Stroke merupakan masalah kesehatan yang menyebabkan perubahan dramatis dalam kehidupan, ${ }^{1}$ penyebab utama kecacatan di seluruh dunia, dan penyebab utama kematian ketiga. ${ }^{2-4}$ Di Indonesia, stroke dilaporkan sebagai penyebab utama kematian pada individu di atas usia lima tahun dengan mayoritas adalah stroke iskemik. ${ }^{1}$

Stroke iskemik akut terjadi ketika ada oklusi tiba-tiba dari suplai darah arteri ke bagian otak, dan paling sering dimanifestasikan dengan defisit neurologis fokal. ${ }^{5} \mathrm{Hal}$ ini mengurangi kualitas hidup dan menyebabkan disabilitas jangka panjang. ${ }^{6-7}$ Angka kejadian dan angka mortalitasnya juga meningkat seiring peningkatan usia. ${ }^{8}$ Sekitar 23\% orang meninggal dalam 30 hari awitan dan $60-70 \%$ meninggal dalam waktu tiga tahun., 3,6

Inflamasi pascaiskemik di otak dapat terjadi akibat mekanisme injury sekunder setelah terjadinya iskemia pada stroke. Stroke menstimulasi respons inflamasi akibat beberapa faktor, seperti hipoksia, stres, debris dari sel yang mengalami nekrosis dan oksigen reaktif. Inflamasi merupakan faktor risiko independen terjadinya stroke iskemik, yang perlu dihambat untuk mengurangi perburukan oklusi pada pembuluh darah akibat plak aterosklerotik. ${ }^{3,10}$

Aterosklerosis adalah penyakit inflamasi kronis yang ditandai dengan pembentukan lipid dan plak yang mengandung sel imun pada lapisan intima yang sering menjadi penyebab utama penyakit jantung dan pembuluh darah maupun stroke. ${ }^{11-12}$ Leukosit merupakan sel mediator inflamasi yang berperan penting, yang akan meningkat bila terdapat kerusakan akut pada sel-sel tubuh. Sel yang meningkat tersebut dianggap sebagai penanda kerusakan akut dari jaringan otak yang mengalami iskemia serta digunakan untuk mengetahui tingkat keparahan dan prognosis stroke iskemik akut.,

Studi model eksperimental stroke menunjukkan bahwa dalam beberapa menit pascaiskemia fokal terdapat aktivasi mikroglia di area iskemik diikuti pergerakan leukosit menuju daerah yang mengalami iskemia. ${ }^{3}$ Jumlah peningkatan leukosit total dikaitkan dengan peningkatan insiden penyakit pembuluh darah dan infark serebral. Akumulasi neutrofil dimulai dalam 6-12 jam dari onset, meningkat selama 24 jam, mencapai puncak dalam 48-72 jam, dan akhirnya digantikan oleh sel mononuklear dalam 4-6 hari. $^{2}$

Kaskade iskemik mengawali inisiasi berbagai proses termasuk inflamasi, produksi oksida nitrat, kerusakan radikal bebas, dan apoptosis yang berperan pada cedera jaringan. Pada iskemia otak, terjadi perubahan molekular termasuk perubahan dalam signal sel, transduksi sinyal, metabolisme, dan regulasi/ekspresi gen. Inflamasi terjadi baik oleh komponen molekuler maupun seluler pada permukaan sel endotel mikrovaskular. ${ }^{2,10}$

Dengan terjadinya iskemia otak, mikroglia, astrosit, sel endotel, dan neuron akan mengeluarkan sejumlah sitokin, seperti interleukin-1 $\beta$ (IL-1 $\beta$ ) dan tumor necrosis factor $\alpha$ (TNF $\alpha$ ), yang memungkinkan rekrutmen leukosit, aktivasi, dan adhesi ke endotelium dari mikrovaskular otak. ${ }^{2}$ Akibat keluarnya sitokinsitokin inflamatori ini, terjadi peningkatan kadar leukosit, migrasi makrofag dan neutrofil menuju area yang terjadi kerusakan jaringan, termasuk indikator inflamasi perifer seperti serum interleukin-6, c-reaktif protein (CRP). ${ }^{10}$ Leukosit yang telah aktif ini akan menyumbat saluran pembuluh darah, kemudian terjadi transmigrasi menuju area infark bersamaan dengan monosit/makrofag., ${ }^{2,10-11}$

Neutrofil berperan penting terhadap perkembangan dan kestabilan plak aterosklerotik. Neutrofil melepaskan autacoids, yang berperan dalam vasokonstriksi dan agregasi platelet. Monosit diketahui juga berperan dalam patogenesis aterosklerosis. Monosit derivat makrofag melepaskan sitokin-sitokin dan radikal bebas lainnya yang dapat menyebabkan injuri sel-sel endotel dan pembentukan trombus. Selain itu, limfosit berperan dalam kondisi inflamasi kronik dan limfosit $\mathrm{T}$ berhubungan dengan kejadian iskemia kardiovaskular dan stroke iskemik berulang. ${ }^{3,9}$

Beberapa studi menunjukkan bahwa terdapat hubungan langsung antara respons inflamasi akut dengan tingkat keparahan stroke. Semakin tinggi kadar leukosit, menunjukkan semakin parah kerusakan iskemik otak, semakin banyak kerusakan 
otak, semakin parah disabilitas dan mortalitas yang ditimbulkan. ${ }^{3,9,13}$ Terdapat peningkatan studistudi dan bukti lainnya yang mengatakan bahwa proses inflamasi merupakan dogma sentral dalam pembentukan dan perkembangan terjadinya aterosklerosis, yang mendasari patogenesis iskemia serebral. $^{2}$

Studi Furlan dkk menunjukkan bahwa kadar leukosit yang lebih tinggi saat masuk RS pada stroke iskemik akut dikaitkan dengan prognosis yang lebih buruk sehubungan dengan tingkat gangguan dan disabilitas, risiko stroke iskemik lebih lanjut, dan mortalitas dalam 30 hari. ${ }^{4}{ }^{14}$ Penelitian yang dilakukan oleh Zia dkk menunjukkan tidak terdapat hubungan antara total leukosit dengan tingkat mortalitas pada pasien stroke iskemik. Namun Peng dkk dan Nardi dkk mendapatkan hubungan tidak langsung antara kadar leukosit dengan prediksi mortalitas pada pasien stroke iskemik. ${ }^{15-17}$ Oleh karena masih perdebatan, perlu dikaji kembali hubungan antara kadar leukosit dengan prognosis setelah onset stroke iskemik akut. ${ }^{3}$

\section{TUJUAN}

Mengetahui hubungan antara kadar leukosit terhadap manifestasi klinis pasien stroke iskemik onset akut pada saat masuk dan keluar perawatan berdasarkan skor National Institutes of Health Stroke Scale (NIHSS).

\section{METODE}

Penelitian observasional analitik prospektif dengan rancangan kohort terhadap semua pasien stroke iskemik onset akut yang dirawat di RSUD Wangaya, Denpasar, pada bulan Januari hingga September 2018.

Data diambil dari rekam medis pasien, meliputi identitas, gejala klinis, pemeriksaan fisik, serta hasil pemeriksaan leukosit saat awal masuk dan di akhir perawatan. Kriteria inklusi adalah onset stroke iskemik 3 hari di RSUD dengan kriteria dinyatakan leukositosis jika leukosit lebih dari $10.000 / \mathrm{mm}^{3}$. Adapun kriteria eksklusi adalah terdapat penyakit infeksi lain (sepsis ataupun fokus infeksi lainnya), meninggal dunia, memiliki riwayat stroke sebelumnya, kesadaran menurun akibat penyebab komorbid lainnya seperti metabolik, koma hiperglikemia, terdapat gabungan stroke hemoragik dan iskemik, terdapat riwayat kelainan darah, gangguan ginjal, riwayat alergi, ataupun gangguan hati.

Subjek dilakukan penilaian NIHSS pada saat awal masuk dan keluar perawatan, serta perbaikan diantaranya. Interpretasi skor NIHSS 1-4: stroke ringan; 5-15: moderat; 16-20: moderat-berat: dan 2142: stroke berat. Skor NIHSS dinyatakan perbaikan jika terdapat penurunan skor sebanyak 2 atau lebih.

Data dianalisis secara statistik menggunakan program SPSS 24 for windows dengan variabel independen berupa kadar leukosit pada awal masuk, sedangkan variabel dependen berupa manifestasi klinis berdasarkan skor NIHSS pada saat awal dan keluar perawatan, serta perbaikan skor diantaranya.

Analisis bivariat antara kadar leukosit terhadap manifestasi klinis menggunakan uji Chisquare. Untuk menilai hubungan kadar leukosit dengan skor NIHSS digunakan uji Mann-Whitney. Dihitung pula perbandingan insiden perbaikan manifestasi klinis pasien berdasarkan skor NIHSS antar 2 kelompok (kelompok leukosit normal dan kelompok leukositosis) yang disebut risiko relatif (RR). Tingkat kemaknaan dinyatakan dengan $\mathrm{p}<0,05$ dengan interval kepercayaan 95\%.

\section{HASIL}

Didapatkan 76 subjek yang dibagi menjadi 2 kelompok, yaitu masing-masing 38 subjek pada kelompok dengan leukosit normal dan kelompok dengan leukositosis (Tabel 1). Mayoritas subjek adalah laki-laki (57,9\%) dengan rerata usia $61,83 \pm 12,11$ tahun, menderita hipertensi $(86,8 \%)$, dan memiliki skor NIHSS kategori ringan $(44,7 \%)$. Rerata leukosit subjek adalah $9.953,42 / \mathrm{mm}^{3}$, sedangkan rerata skor NIHSS saat masuk dan keluar adalah 6 dan 7 (moderat).

Kelompok subjek leukosit normal (Tabel 2), didominasi oleh subjek laki-laki $(78,9 \%)$ dan rerata kadar leukosit $7.612 / \mathrm{mm}^{3}$, sedangkan pada kelompok leukositosis mayoritas perempuan $(63,2 \%)$ dan rerata kadar leukosit $12.294 / \mathrm{mm}^{3}$. Rerata skor NIHSS saat masuk pada kelompok leukosit normal adalah 5 (moderat) dan pada kelompok dengan leukositosis 
Tabel 1. Karakteristik Pasien Stroke Iskemik Onset Akut (n=76)

\begin{tabular}{|c|c|c|}
\hline Karakteristik & n (\%) & Rerata \pm SD \\
\hline \multicolumn{3}{|l|}{ Jenis Kelamin } \\
\hline - Laki-laki & $44(57,9)$ & \\
\hline - Perempuan & $32(42,1)$ & \\
\hline Usia (Tahun) & & $61,83 \pm 12,11$ \\
\hline \multicolumn{3}{|l|}{ Hipertensi } \\
\hline - $\mathrm{Ya}$ & $66(86,8)$ & \\
\hline - Tidak & $10(13,2)$ & \\
\hline \multicolumn{3}{|l|}{ Diabetes Melitus } \\
\hline - Ya & $19(25)$ & \\
\hline - Tidak & $57(75)$ & \\
\hline Kadar Leukosit & & $9.953,42 \pm 2.822,43$ \\
\hline - Normal & $38(50)$ & \\
\hline - Meningkat & $38(50)$ & \\
\hline \multicolumn{3}{|l|}{ Skor NIHSS } \\
\hline - NIHSS masuk & & $6,76+4,7$ \\
\hline - NIHSS keluar & & $7,20 \pm 9,41$ \\
\hline \multicolumn{3}{|c|}{ Perbaikan Skor NIHSS } \\
\hline - Ada & $35(46,1)$ & \\
\hline - Tidak ada & $41(53,9)$ & \\
\hline \multicolumn{3}{|l|}{ Kategori Stroke } \\
\hline - Ringan & $34(44,7)$ & \\
\hline - Moderat & $38(50)$ & \\
\hline - Moderat-berat & $1(1,3)$ & \\
\hline - Berat & $3(3,9)$ & \\
\hline
\end{tabular}

NIHSS: National Institutes of Health Stroke Scale.

adalah 8 (moderat). Adapun rerata skor NIHSS pada kelompok leukosit normal saat pasien keluar adalah 3 (ringan) dan 11 (moderat) pada kelompok leukositosis.

Tabel 2. Rerata Variabel pada Kedua Kelompok $(n=76)$

\begin{tabular}{lcc}
\hline \multirow{2}{*}{ Variabel } & \multicolumn{2}{c}{ Kadar Leukosit } \\
\cline { 2 - 3 } & $\begin{array}{c}\text { Normal (n=38) } \\
\mathbf{n ~ ( \% )}\end{array}$ & $\begin{array}{c}\text { Meningkat }(\mathbf{n}=\mathbf{3 8}) \\
\mathbf{n}(\%)\end{array}$ \\
\hline Jenis Kelamin & & $14(36,8)$ \\
- Laki-laki & $30(78,9)$ & $24(63,2)$ \\
- Perempuan & $8(21,1)$ & $12.294 / \mathrm{mm}^{3}$ \\
Kadar Leukosit & $7.612 / \mathrm{mm}^{3}$ & \\
Skor NIHSS & & 8 \\
- Masuk & 5 & 11 \\
- Keluar & 3 & \\
\hline
\end{tabular}

NIHSS: National Institutes of Health Stroke Scale.
Berdasarkan uji Mann-Whitney (Tabel 3) didapatkan hubungan bermakna antara kadar leukosit pasien pada saat masuk terhadap derajat beratnya stroke subjek berdasarkan skor NIHSS saat masuk $(p=0,001)$ dan keluar RS $(p=0,000)$. Pada saat awal perawatan, subjek dengan kadar leukosit yang normal akan lebih cenderung mengalami stroke ringan dan tidak ada yang mengalami keadaan stroke berat. Sebaliknya subjek dengan leukositosis akan cenderung mengalami stroke mederat bahkan berat. Demikian pula pada saat selesai perawatan, subjek dengan kadar leukosit yang normal akan lebih cenderung mengalami perbaikan stroke-nya menjadi lebih ringan atau bahkan tidak bergejala, sedangkan pada kelompok leukositosis subjek menjadi lebih banyak yang moderat dan berat.

Tabel 4 menunjukkan kelompok subjek dengan kadar leukosit normal lebih banyak mengalami perbaikan skor NIHSS selesai perawatan sebanyak $60,5 \%$ secara bermakna dibandingkan kelompok leukositosis (31,6\%). Berdasarkan uji Chi-square, didapatkan hubungan bermakna antara kadar leukosit subjek pada saat masuk (pada kedua kelompok) terhadap manifestasi klinis subjek saat keluar RS berdasarkan ada tidaknya perbaikan skor NIHSS ( $p=0,012)$. Risiko relatif (RR) subjek dengan kadar leukosit normal untuk mengalami perbaikan manifestasi klinis selesai perawatan adalah dua kali lipat dibandingkan dengan subjek leukositosis (RR 1,$9 ; 95 \%$ IK $1,1-3,3 ; p=0,012$ ).

\section{PEMBAHASAN}

Pada penelitian ini didapatkan bahwa subjek dengan kadar leukosit normal saat masuk RS memiliki kategori stroke yang lebih ringan dibandingkan subjek dengan leukositosis. Demikian pula manifestasi klinis saat keluar RS subjek dengan kadar leukosit normal hampir dua kali lipat lebih baik dibandingkan subjek dengan leukositosis. Hasil penelitian ini sesuai dengan Furlan dkk bahwa kadar leukosit yang lebih tinggi saat masuk RS pada stroke iskemik akut berkaitan dengan prognosis yang lebih buruk dalam hal tingkat gangguan dan disabilitas, risiko stroke iskemik lebih lanjut, dan mortalitas dalam 30 hari. $^{4,14}$ 
Tabel 3. Hubungan Kadar Leukosit dengan Skor NIHSS Saat Masuk dan Keluar RS (n=76)

\begin{tabular}{|c|c|c|c|c|c|c|}
\hline \multirow{2}{*}{ Kadar Leukosit } & \multicolumn{4}{|c|}{ Kategori Stroke Berdasarkan Skor NIHSS Masuk } & \multirow[b]{2}{*}{$\mathbf{n}$} & \multirow[b]{2}{*}{ p* } \\
\hline & $\begin{array}{c}\text { Ringan } \\
\text { n (\%) }\end{array}$ & $\begin{array}{c}\text { Moderat } \\
\text { n (\%) }\end{array}$ & $\begin{array}{c}\text { Moderat-Berat } \\
\text { n (\%) }\end{array}$ & $\begin{array}{l}\text { Berat } \\
\text { n (\%) }\end{array}$ & & \\
\hline \multicolumn{7}{|l|}{ Saat Masuk RS } \\
\hline - Normal & $24(63,2)$ & $13(34,2)$ & $1(2,6)$ & $0(0,0)$ & 38 & \\
\hline - Meningkat & $10(26,3)$ & $25(65,8)$ & $0(0,0)$ & $3(7,9)$ & 38 & 0,001 \\
\hline Total & $34(44,7)$ & $38(50)$ & $1(1,3)$ & $3(3,9)$ & 76 & \\
\hline \multicolumn{7}{|l|}{ Saat Keluar RS } \\
\hline - Normal & $8(21,1)$ & $21(55,3)$ & $9(23,7)$ & $0(0,0)$ & 38 & \\
\hline - Meningkat & $1(2,6)$ & $10(26,3)$ & $21(55,3)$ & $1(2,6)$ & 38 & 0,000 \\
\hline Total & $9(11,8)$ & $31(40,8)$ & $30(39,5)$ & $1(1,3)$ & 76 & \\
\hline
\end{tabular}

*Uji Mann-Whitney; $p<0,05$ bermakna.

Tabel 4. Hubungan Perbaikan Klinis Subjek terhadap Kadar Leukosit (n=76)

\begin{tabular}{|c|c|c|c|c|}
\hline \multirow[b]{2}{*}{ Kadar Leukosit } & \multicolumn{2}{|c|}{ Perbaikan Skor NIHSS } & \multirow[b]{2}{*}{$\mathbf{n}$} & \multirow[b]{2}{*}{$\mathbf{p}^{*}$} \\
\hline & $\begin{array}{c}\text { Tidak Ada Perbaikan } \\
\text { n (\%) }\end{array}$ & $\begin{array}{c}\text { Perbaikan } \\
\text { n (\%) }\end{array}$ & & \\
\hline Normal & $15(39,5 \%)$ & $23(60,5 \%)$ & 38 & \multirow{2}{*}{0,012} \\
\hline \multirow[t]{3}{*}{ Meningkat } & $26(68,4 \%)$ & $12(31,6 \%)$ & 38 & \\
\hline & $\mathrm{RR}=0,577$ & $\mathrm{RR}=1,917$ & & \\
\hline & IK $95 \%=0,368-0,904$ & IK $95 \%=1,124-3,269$ & & \\
\hline
\end{tabular}

*Uji Chi-square; $\mathrm{p}<0,05$ bermakna.

Leukosit merupakan sel mediator inflamasi yang berperan penting, yang akan meningkat bila terdapat kerusakan akut pada sel-sel tubuh. Sel yang meningkat tersebut dianggap sebagai penanda kerusakan akut dari jaringan otak yang mengalami iskemia dan digunakan untuk mengetahui tingkat keparahan dan prognosis stroke iskemik akut. ${ }^{3,9}$

Inflamasi pascaiskemik di otak dapat terjadi akibat mekanisme injuri sekunder oleh beberapa faktor, seperti hipoksia, stres, debris dari sel yang mengalami nekrosis, dan oksigen reaktif. ${ }^{3,10}$ Kaskade iskemik mengawali inisiasi berbagai proses termasuk inflamasi, produksi oksida nitrat, kerusakan radikal bebas, dan apoptosis yang berperan dalam cedera jaringan. ${ }^{2,10}$ Akibat keluarnya sitokin-sitokin inflamatori ini, terjadi peningkatan kadar leukosit, migrasi makrofag dan neutrofil menuju area yang cedera. Leukosit yang telah aktif ini akan menyumbat saluran pembuluh darah, kemudian bermigrasi menuju area infark bersama monosit/makrofag. ${ }^{2,10-11}$

Berdasarkan hal itu, penentuan kadar leukosit dapat menjadi salah satu pencegahan perburukan dan prognosis stroke iskemik akut untuk memulai reperfusi yang efektif dan lebih awal. ${ }^{1}$ Hal ini sesuai dengan Peng dkk dan Nardi dkk bahwa didapatkan hubungan tidak langsung antara kadar leukosit dengan prediksi mortalitas pada pasien stroke iskemik. ${ }^{17}$

Keterbatasan penelitian ini adalah kenaikan kadar leukosit akibat penyakit infeksi lain hanya berdasarkan tanda sepsis ataupun fokus infeksi lainnya, tanpa dilakukan pemeriksaan laboratorium lebih lanjut seperti kadar C-reactive protein (CRP), interleukin, dan sebagainya.

\section{KESIMPULAN}

Kadar leukosit pasien stroke iskemik akut saat masuk ke RS memiliki hubungan yang bermakna baik terhadap skor NIHSS awal dan saat keluar perawatan. Pasien dengan stroke iskemik onset akut dengan kadar leukosit yang normal saat masuk cenderung memiliki perbaikan manifestasi klinis saat pasien keluar dari RS dua kali lebih baik daripada pasien dengan leukositosis. 


\section{DAFTAR PUSTAKA}

1. Wicaksana HY, Adrianto Y, Rehatta NM. Correlation between white blood cell count and clinical severity based on NIHSS in acute ischemic stroke patients. Bali Med J. 2017;6(1):130.

2. Deb P, Sharma S, Hassan KM. Pathophysiologic mechanisms of acute ischemic stroke: An overview with emphasis on therapeutic significance beyond thrombolysis. Pathophysiology. 2010;17(3):197-218.

3. K Srinivas, HA Krisnhamurthy. Prognostic significance of total leucocytes count in acute ischemic stroke. Int J Contemp Med Res. 2017;4(4):833-36.

4. Chaturvedi P, Mehrotra V, Saxena Y, Manna S. Correlation of serum nitric oxide with haematological and biochemical parameters in acute ischaemic stroke patients. J Clin Diagn Res. 2018;12(6):25-28.

5. Khandelwal P, Yavagal DR, Sacco RL. Acute ischemic stroke intervention. J Am Coll Cardiol. 2016;67(22):2631-44.

6. Parmar P, Sumariaa S, Hashi S. Stroke: Classification and diagnosis. Clinical Pharmacist. 2011;3:200.

7. Ojaghihaghighi S. Comparison of neurological clinical manifestation in patients with hemorrhagic and ischemic stroke. World $\mathrm{J}$ Emerg Med. 2017;8(1):34.

8. Kanyal N. The science of ishemic stroke: Pathophysiology \& pharmacological treatment. IJPRR. 2015;4(10):65-84.

9. Liang J, Gu X, Liu W, Sun J, Ma Q, Tong W. Relationship between leukocyte and neutrophil counts and early prognosis after acute ischemic stroke. Int $\mathrm{J}$ Clin Exp Med. 2016;9(2):4308-15.

10. Ye L, Cai R, Yang M, Qian J, Hong Z. Reduction of the systemic inflammatory induced by acute cerebral infarction through ultra-early thrombolytic therapy. Exp Ther Med. 2015; 10(4):1493-8.

11. Liu Y, Kong X, Wang W, Fan F, Zhang Y, Zhao M, dkk. Association of peripheral differential leukocyte counts with dyslipidemia risk in Chinese patients with hypertension: Insight from the China Stroke Primary Prevention Trial. J Lipid Res. 2017;58(1):256-66.

12. Arandjelovic-Minic G. Leucocyte count indicates carotid plaque instability in stroke patients. Vojnosanit Pregl. 2016;73(6):515-25.

13. Ganti L, Gilmore RM, Weaver AL, Brown RD. Prognostic value of complete blood count and electrolyte panel during emergency department evaluation for acute ischemic stroke. ISRN Stroke. 2013:2013:1-5.

14. Furlan JC, Vergouwen MD, Fang J, Silver FL. White blood cell count is an independent predictor of outcomes after acute ischaemic stroke. Eur J Neurol. 2014;21(2):215-22.

15. Iranmanesh F, Zia-Sheykholeslami N, Vakilian A, Sayadi A. Relationship between white blood cell count and mortality in patients with acute ischemic stroke. ZJRMS. 2014;16(6):16-19.

16. Zia E, Melander O, Bjorkbacka H, Hedblad B, Engstrom G. Total and differential leucocyte counts in relation to incidence of stroke subtypes and mortality: a prospective cohort study: Leucocytes and stroke subtypes. J Intern Med. 2012;272(2):298-304.

17. Peng Y, Wang D, Zhang J, Xue X, Wang Z, Tong W, dkk. Relationship between white blood cell count at admission and short term outcome in patients with acute cerebral infarction. Clin Invest Med. 2011;34(4):249. 